\title{
Potential role of children in the household transmission of SARS-CoV-2 infection in Catalonia (Spain)
}

\author{
Antoni Soriano-Arandes ${ }^{1 *}$, Berta Ferran ${ }^{1}$, Magda Campins ${ }^{2}$, Juliana Esperalba-Esquerra ${ }^{3}$, \\ Juliana Reyes-Urueña ${ }^{4,5}$, Uxue Lazcano ${ }^{6}$, Anna Gatell7, Pepe Serrano ${ }^{7}$, Xavier Bruna ${ }^{8}$, \\ Ramon Capdevila ${ }^{9}$, María Esteller ${ }^{10}$, Andrés Antonn ${ }^{3}$, Jordi Gómez i Prat ${ }^{2}$, Gloria Ruiz ${ }^{11}$, \\ Anna Fàbrega ${ }^{12}$, Neus Rius ${ }^{13}$, Marina Fenoy ${ }^{14}$, Núria López ${ }^{15}$, Almudena Sánchez ${ }^{16}$, \\ Miriam Poblet ${ }^{17}$, Anton Foguet ${ }^{18}$, Guillermo García ${ }^{19}$, Teresa Riera ${ }^{20}$, Elisenda \\ Martínez-Carbonell6, Yesika Díaz, ${ }^{41}$, Valentí Pineda ${ }^{22}$, Pere Soler-Palacin ${ }^{1}$ \\ 1 Pediatric Infectious Diseases and Immunodeficiencies Unit, Hospital Universitari Vall d'Hebron, Barcelona, \\ Catalonia, Spain (asoriano@vhebron.net; bertaferranballus@gmail.com; psoler@vhebron.net) \\ 2 Department of Preventive Medicine and Epidemiology, Hospital Universitari Vall d'Hebron, Barcelona, \\ Catalonia, Spain (mcampins@vhebron.net; j.gomez@vhebron.net) \\ ${ }^{3}$ Department of Microbiology, Hospital Universitari Vall d'Hebron, Barcelona, Catalonia, Spain \\ (jesperalba@vhebron.net; aanton@vhebron.net) \\ ${ }^{4}$ Centre Estudis Epidemiolòics sobre les Infeccions de Transmissió Sexual i Sida de Catalunya (CEEISCAT), \\ Agència de Salut Pública de Catalunya, Catalonia, Spain (jmreyes@iconcologia.net; ydiaz@igtp.cat) \\ 5 CIBER Epidemiologia y Salud Pública (CIBERESP), Spain (jmreyes@iconcologia.net) \\ 6 Agència de Qualitat i Avaluació Sanitàries, Agència de Salut Pública de Catalunya, Departament de Salut, \\ Generalitat de Catalunya, Catalonia, Spain (uxue.lazacano@gencat.cat; elisenda.martinezc@gencat.cat) \\ 7 Equip Pediatria Territorial Alt Penedès-Garraf, Institut Català de la Salut, Catalonia, Spain \\ (annagatellcarbo@gmail.com; pepepediatre@gmail.com) \\ 8 EAP Baix Berguedà. Institut Català de la Salut. Catalonia, Spain (xbruna.cc.ics@gencat.cat) \\ 9 EAP Les Borges Blanques, Lleida, Institut Català de la Salut. Catalonia, Spain (capbert@gmail.com) \\ 10 EAP Terres de l'Ebre, Institut Català de la Salut. Catalonia, Spain (maria.esteller@gmail.com) \\ 11 EAP Pirineus i Alt Urgell, Institut Català de la Salut. Catalonia, Spain (gruiz@pediatriadelspirineus.org) \\ 12 EAP Figueres, Alt Empordà, Institut Català de la Salut. Catalonia, Spain (annafabregariera@hotmail.com) \\ 13 Hospital Universitari Sant Joan de Reus, Tarragona, Catalonia, Spain (neusrius@gmail.com) \\ 14 Consorci Sanitari de Terrassa, Barcelona, Catalonia, Spain (marinafenoy@gmail.com) \\ 15 Hospital Universitari del Mar, Barcelona, Catalonia, Spain (nlsnoodles@hotmail.com) \\ 16 CAP Les Hortes, Barcelona, Institut Català de la Salut, Catalonia, Spain (asanva@yahoo.es) \\ 17 CAP Nord Sabadell, Institut Català de la Salut, Catalonia, Spain (miriampoblet@gmail.com) \\ 18 Hospital d'Olot i Equip Pediàtric Territorial Garrotxa i Ripollès (EPTGiR), Catalonia, Spain \\ (afoguet@hospiolot.cat) \\ 19 Hospital Comarcal i Atenció Primària del Vendrell i Camp de Tarragona, Catalonia, Spain \\ (garciaguim@gmail.com) \\ 20 SAP Osona, Institut Català de la Salut, Catalonia, Spain (triera.cc.ics@gencat.cat) \\ 21 The Institute for Health Science Research Germans Trias i Pujol (IGTP), Badalona, Catalonia, Spain \\ (ydiaz@igtp.cat) \\ 22 Consorci Corporació Sanitària Parc Taulí de Sabadell, Catalonia, Spain (vpineda@tauli.cat) \\ * Correspondence: asoriano@vhebron.net; Tel.: +34-639712438 (A.S-A.)
}

\begin{abstract}
We analyzed the characteristics of the Severe Acute Respiratory Syndrome Coronavirus-2 (SARS-CoV-2) infected children during lock-down period in Catalonia (Spain), and their transmission role within the households. Among 295 traced household contacts of 89 pediatric patients, children were classified as final index cases in only $3.4 \%$ of the traced homes.
\end{abstract}

Keywords: SARS-CoV-2; COVID-19; children; household; contact tracing 


\section{Introduction}

Household clusters of coronavirus disease 2019 (COVID-19) may play an essential role in the community transmission of Severe Acute Respiratory Syndrome Coronavirus-2 (SARS-CoV-2) infections, and consequently a risk for spreading the disease to the community [1]. Therefore, household contact tracing studies can be highly effective for COVID-19 prevention [2]. In South Korea, two similar studies demonstrated dissenting transmission rates within households from SARS-CoV-2 infected children [1, 3]. In Europe (French Alps), a study of a cluster with twelve secondary cases included a symptomatic child who attended three schools without transmitting the virus to any of his contacts [4]. Also, in the Netherlands periodic reports from the National Institute of Public Health showed that patients under 20 years play a smaller role in the spread of the infection than adults [5]. However, studies exclusively based on SARS-CoV-2 viral load in respiratory samples suggest a possible role of children in SARS-CoV-2 transmission, even when asymptomatic [6, 7].

On March 13th, as a first measure within a global lockdown, 5,492 Catalonian schools with a total of $1,565,478$ students were closed in an effort to contain the spread of COVID-19 [8].

\section{Materials and Methods}

Catalonia, a northeastern region of Spain with 7.5 million inhabitants -1,581,341 below 20 years of age- with a regional-level governance public health system comprises 7 health sub-regional departments, and more than 400 Primary health-care centers.

The objectives of this project named "COVID-19 pediatric disease in Catalonia" (COPEDI-CAT) were: 1) to describe the epidemiological and clinical characteristics of all the pediatric COVID-19 cases diagnosed in Catalonia (Spain); and 2) to describe the dynamics of the SARS-CoV-2 infection within the household and 3) to assess the children's potential role in its transmission.

This is a retrospective cross-sectional study, including the lock-down period, between 10th March and 31st May 2020 (study-period), to collect data from all pediatric (below 18 years of age) COVID-19 patients who were diagnosed by reverse transcription polymerase-chain-reaction (RT-PCR).

We obtained demographic, epidemiological, and diagnostic data of the pediatric cases through the Catalonian Health Quality and Assessment Agency from five different sources: primary health-care centers, hospitals, emergency departments, the Catalonian Epidemiological Surveillance Network, and the referral laboratories. Thereafter, a telephone survey was applied by expert healthcare workers to the parents or legal guardians of each confirmed SARS-CoV-2 pediatric case to obtain clinical and microbiological information from their household contacts. Finally, SARS-CoV-2 serological investigation was performed to household contacts of all the pediatric cases included in the study to better assess exposure to SARS-CoV-2. All data were registered in a web-based software platform Research Electronic Data Capture (REDCap®) database.

Index case was defined when the child was the first infected within the household considering the chronology of the symptoms and the serology results performed to the contacts as surrogates that reflects the temporality of the infection. Secondary cases were defined when another symptomatic household contact tested positive for SARS-CoV-2 RT-PCR or serology before the child. In co-primary cases we did not find any household contact other than the child testing positive for SARS-CoV-2 RT-PCR or serology, or we were unable to establish temporality within contacts testing positive for SARS-CoV-2 RT-PCR or serology. 
As a project under the supervision of the Catalonian Public Health Agency to support health-policy recommendations on easing the current COVID-19 partial lockdown measures and allowing children back to school safely, ethics approval was not requested initially. However, to perform the microbiological studies to the household contacts, we finally obtained an ethical approval for this purpose and for all the study (PR (AG) 475/2020).

\section{Results}

\subsection{Characteristics of the cases and their household contacts}

\subsubsection{Characteristics of the cases}

The first pediatric case of COVID-19 was identified on March 10th, 2020; by May 31st, 158 cases of children under 18 years had been reported, with a median [IQR] age of 12 [4-16] years (table 1). Temporal distribution showed two different time-peaks, the first in the second half of March likely secondary to infections acquired before lock-down measures, and the second through the second half of April 2020 till the end of May likely due to the increased number of RT-PCR performed between March (n=987) and May (n=8,073) (figure 1 and figure 2). Nearly 20\% (31/158) needed hospital admission ( 5 in the pediatric intensive care unit), with a higher non-significant percentage in the under 3 years age-group $(35.7 \% ; 10 / 28)$, and in female $(24.4 \% ; 21 / 86)$.

Complete clinical and household contacts data were actively obtained from $56.3 \%(89 / 158)$ of the patients (table 1); 43.7\% (69/158) were excluded for the contact-tracing analysis because different reasons (figure 3). The median [IQR] time between the diagnosis date of the case and the information collected from household contacts was 121 [92-138] days.

Fever $(59.6 \% ; 50 / 89)$ and cough $(49.4 \% ; 44 / 89)$ were the most frequent symptoms while $21.3 \%(19 / 89)$ were asymptomatic (table 1$)$. One death was reported $(0.6 \%)$, and six patients had some, mostly minor, sequelae.

\subsubsection{Characteristics of the household contacts}

A total of 295 household contacts were linked to these 89 pediatric cases. After completing the contact-tracing study, children were defined as index cases in at $3.4 \%$; the rest of children were classified as co-primary (40.4\%) or were secondary cases to adults (56.2\%) (table 2 ).

\subsection{Figures, Tables and Schemes}

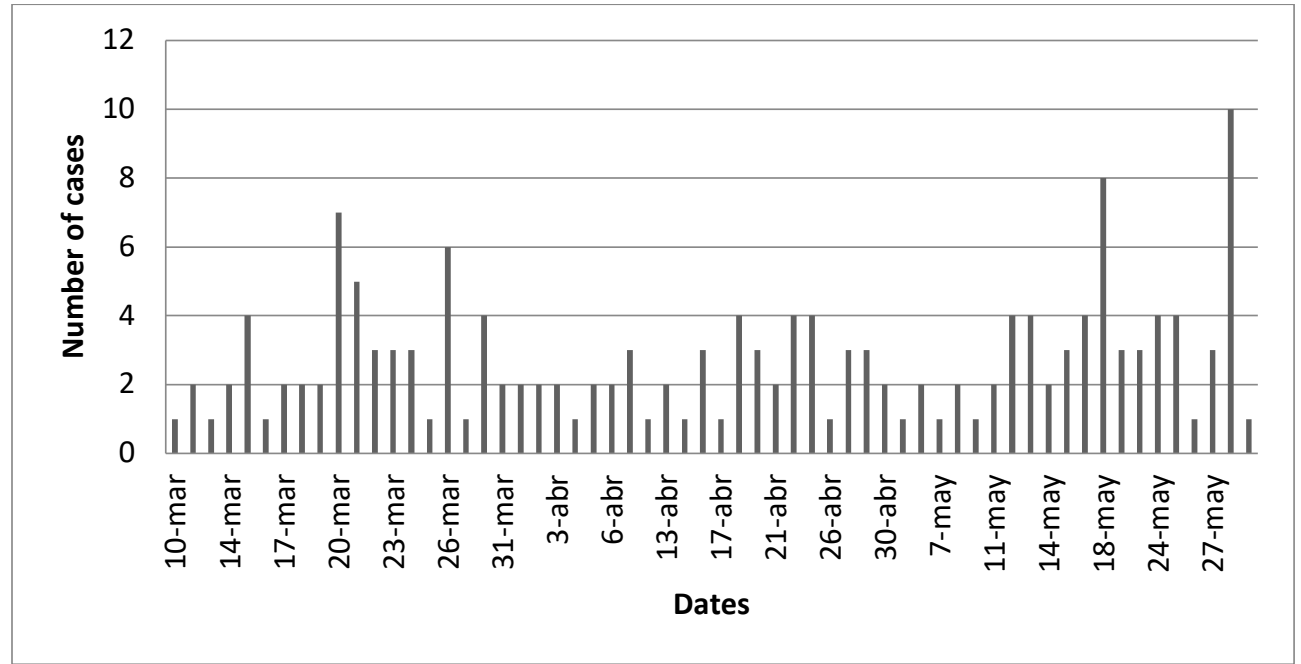

Figure 1. Temporal distribution of SARS-CoV-2 pediatric cases between March and May 2020 


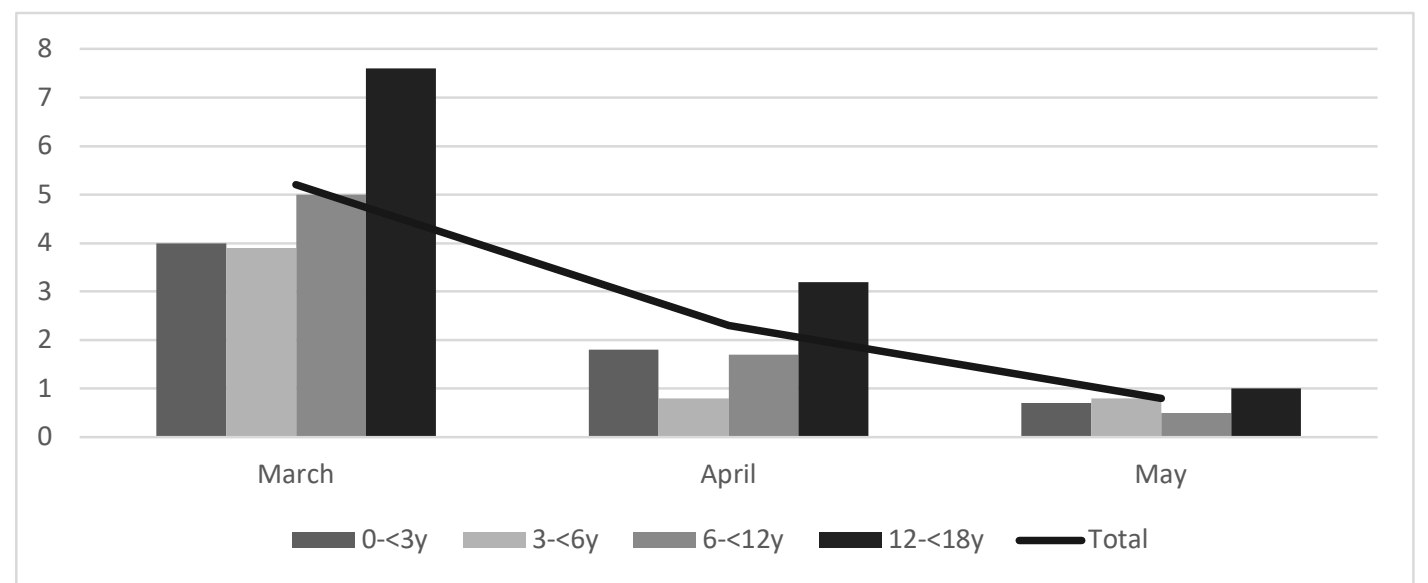

Figure 2. Distribution of the percentage of positive SARS-CoV-2 RT-PCR tests by month and by age- groups

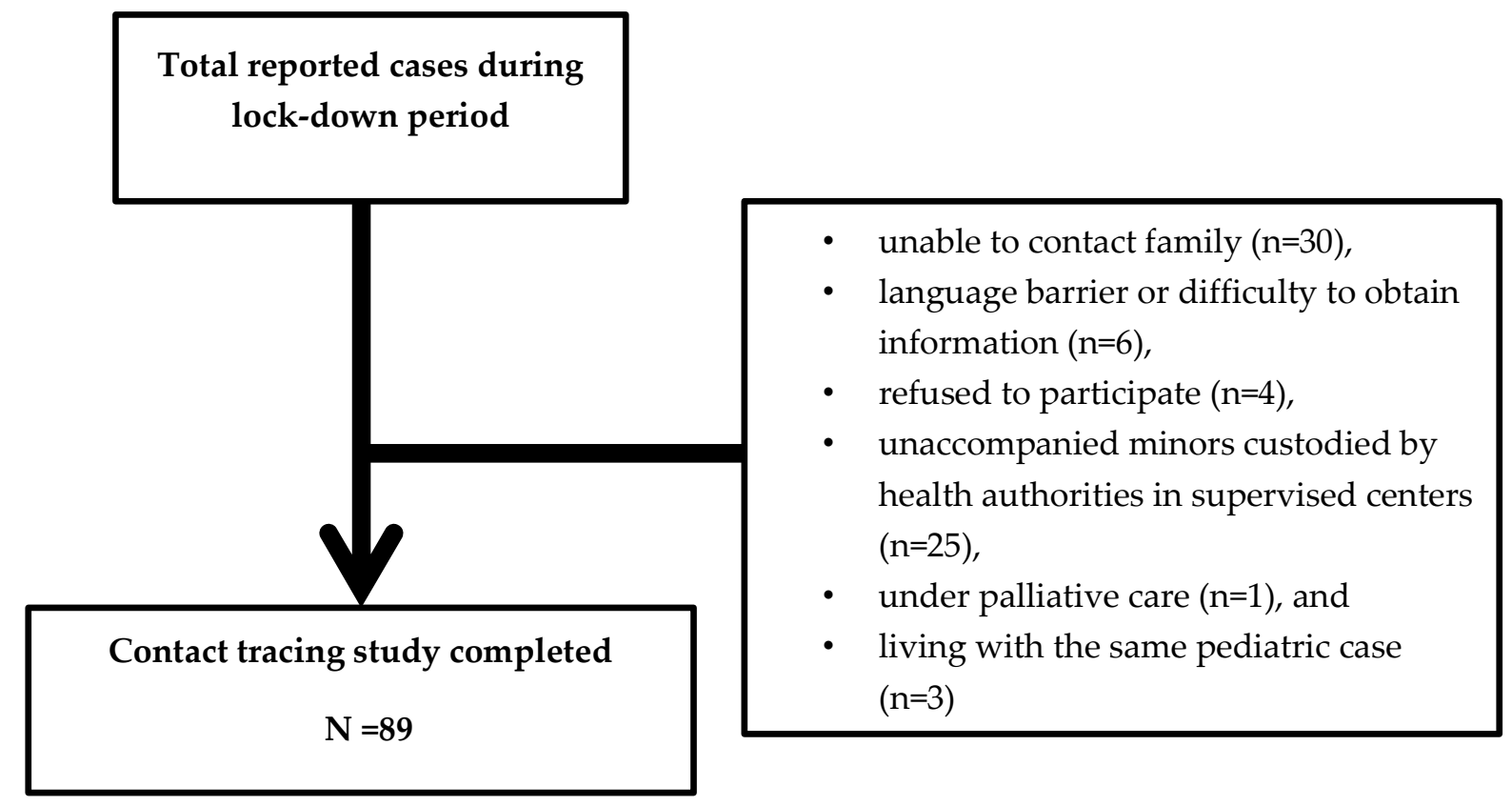

Figure 3. Flow-chart of the study analysis 
Table 1. Epidemiological and clinical characteristics of included patients.

\begin{tabular}{|c|c|c|}
\hline Characteristics & Number of cases & $\%$ \\
\hline \multicolumn{3}{|l|}{ Sex $(n=158)$} \\
\hline Male & 72 & 46.0 \\
\hline Female & 86 & 54.0 \\
\hline \multicolumn{3}{|l|}{ School age-group $(n=158)$} \\
\hline 0 to $<3 \mathrm{y}$-old & 28 & 17.7 \\
\hline 3 to $<6 y$-old & 18 & 11.4 \\
\hline 6 to $<12$ y-old & 30 & 19.0 \\
\hline 12 to $<16 y$-old & 40 & 25.3 \\
\hline 16 to $<18 y$-old & 42 & 26.6 \\
\hline \multicolumn{3}{|l|}{ Admission to hospital (yes) $(n=158)$} \\
\hline 0 to $<3 \mathrm{y}$-old & 10 & 35.7 \\
\hline 3 to $<6 y$-old & 3 & 16.7 \\
\hline 6 to $<12$ y-old & 3 & 10.0 \\
\hline 12 to $<16 y$-old & 7 & 17.5 \\
\hline 16 to $<18 y$-old & 8 & 19.0 \\
\hline Days of hospital stay $(n=89)$ (median/IQR) & 5.5 & 3-12.25 \\
\hline Admission to PICU (yes) & 5 & 5.6 \\
\hline \multicolumn{3}{|l|}{ Symptoms (n=89) } \\
\hline Asymptomatic & 19 & 21.3 \\
\hline Fever $\left(>37.5^{\circ} \mathrm{C}\right)$ & 53 & 59.6 \\
\hline Cough & 44 & 49.4 \\
\hline Fatigue & 36 & 40.5 \\
\hline Dyspnea & 28 & 31.5 \\
\hline Diarrhea & 20 & 22.5 \\
\hline Abdominal pain & 17 & 19.1 \\
\hline Vomiting & 13 & 14.6 \\
\hline Exanthema & 13 & 14.6 \\
\hline Taste or smell alteration & 12 & 13.5 \\
\hline Headache & 9 & 10.1 \\
\hline Other & 11 & 12.4 \\
\hline Comorbidities $(\mathrm{n}=89)(\mathrm{yes})^{\#}$ & 23 & 25.8 \\
\hline \multicolumn{3}{|l|}{ Final outcome } \\
\hline Recovered & 83 & 93.3 \\
\hline Sequelae* $^{*}$ & 6 & 6.7 \\
\hline
\end{tabular}

\#Comorbidities associated with hospitalization: severe congenital heart disease, and chronic lung disease (not including asthma)

*Sequelae: chronic inflammatory syndrome, failure to thrive, post-COVID-19 persistent fever, dilated cardiomyopathy, persistent anosmia and dysgeusia, weight loss and anorexia 
Table 2. Epidemiological and clinical characteristics of included patients.

\begin{tabular}{|c|c|c|}
\hline Variable & Median & IQR \\
\hline Household contacts (n) & 3 & $3-4$ \\
\hline \multirow[t]{2}{*}{ Age of the contacts (years) } & 35 & $14-46$ \\
\hline & $\mathbf{N}$ & $\%$ \\
\hline Sex (female) & 152 & 51.5 \\
\hline \multicolumn{3}{|l|}{ Familiar relationship } \\
\hline Father & 75 & 25.4 \\
\hline Mother & 88 & 29.8 \\
\hline Siblings & 109 & 37.0 \\
\hline Grandparents & 11 & 3.7 \\
\hline Others & 12 & 4.1 \\
\hline Symptoms (yes) & 153 & 51.9 \\
\hline \multicolumn{3}{|l|}{ SARS-CoV-2 Serology result } \\
\hline Positive & 78 & 26.4 \\
\hline Negative & 81 & 27.5 \\
\hline Not performed & 136 & 46.1 \\
\hline Hospitalized & 17 & 5.8 \\
\hline Admitted to the ICU & 4 & 1.4 \\
\hline $\begin{array}{c}\text { Household contacts with a clinically or } \\
\text { microbiologically confirmed COVID-19 diagnosis }\end{array}$ & $\mathbf{N}$ & $\%$ \\
\hline Yes & 178 & 60.3 \\
\hline No & 47 & 15.9 \\
\hline Unknown & 70 & 23.7 \\
\hline Case classification & $\mathbf{N}$ & $\%(C I 95 \%)$ \\
\hline Final index case & $3^{*}$ & $\begin{array}{c}3.4 \\
(0.0-7.1)\end{array}$ \\
\hline Co-primary case & 36 & $\begin{array}{c}40.4 \\
(30.3-50.6)\end{array}$ \\
\hline $\begin{array}{l}\text { None of household contacts with clinical or laboratory } \\
\text { confirmed diagnosis }\end{array}$ & $5 / 36$ & 13.9 \\
\hline $\begin{array}{c}\text { One household contact with clinical or laboratory } \\
\text { confirmed diagnosis }\end{array}$ & $7 / 36$ & 19.4 \\
\hline $\begin{array}{c}\text { Two household contacts with clinical or laboratory } \\
\text { confirmed diagnosis }\end{array}$ & $5 / 36$ & 13.9 \\
\hline $\begin{array}{c}\text { Three household contacts with clinical or laboratory } \\
\text { confirmed diagnosis }\end{array}$ & $5 / 36$ & 13.9 \\
\hline Secondary cases & 50 & $\begin{array}{c}56.2 \\
(45.9-66.5) \\
\end{array}$ \\
\hline
\end{tabular}

${ }^{*}$ Three final index cases were: one 17-year-old boy, one 17-year-old girl, and a 5-year-old girl.

\section{Discussion}

The clinical impact of COVID-19 on pediatric patients in Catalonia (Spain) during confinement was low compared to adults, and most presented as mild cases. The median age of the cases was 12 years, however a third of younger children were admitted to the hospital due to a possible bias for considering them at higher risk for COVID-19 complications at the beginning of the epidemic. 
Pediatric patients were classified as final index cases, and responsible for household SARS-CoV-2 transmission, in only $3.4 \%$ of the contact-traced homes which is much lower than other studies $[1,9]$. In contrast, in nearly $60 \%$ of the cases the final index case was an adult. To note, about 6 out of 10 household contacts were clinically and/or microbiologically diagnosed with COVID-19, most of them with mild symptoms without hospitalization, demonstrating a high transmission rate among household contacts (data not shown).

The study has some limitations, firstly because SARS-CoV-2 RT-PCR was mostly performed only to the clinically significant cases during the study-period. Secondly, the number of cases is small diminishing the ability to detect differences when comparing transmission between index and secondary children cases. Also, there is a potential memory bias regarding symptoms and the dynamics of the transmissibility of the infection. The rate of infected contacts may have been underestimated, as not all contacts were tested for RT-PCR and some serological results from them have been unable to perform. The prospective study currently ongoing will probably overcome most of these limitations, adding information in a different epidemiological context.

With the results of our study, and as other authors reported previously, children do not appear to be the responsible for household clusters of infection and are unlikely to be the main drivers of the pandemic [10-12]. Interventions aimed at children might have a small impact on reducing SARS-CoV-2 transmission, particularly if the transmissibility of subclinical infections is low [11]. Moreover, most children with comorbidities should be allowed to go back to school, as showed in our study where only severe cardiopathies or chronic lung diseases (excluding asthma) were associated to hospitalizations. Recent results demonstrated that child-to-child transmission in schools and childcare facilities is uncommon and not the primary cause of SARS-CoV-2 infection [13, 14]. School closure seems to be an inefficient measure to contain COVID-19 disease [15]. Active surveillance is needed to confirm the safety of this approach.

Author Contributions: Conceptualization, A.S-A., and P.S-P.; methodology, A.S-A., M.C., J.R-U., U.L., E.M-C., Y.D., and P.S-P.; software, U.L., E.M-C., J.R-U., and Y.D.; validation, A.S-A., J.R-U., U.L., E.M-C., Y.D., and P.S-P.; formal analysis, J.R-U., and Y.D.; investigation, A.S-A., B.F., M.C., J.E., J.R-U., U.L., A.G., P.S., X.B., R.C., M.E., A.A., J.G-P., G.R., A.F., N.R., M.F., N.L., A.S., M.P., A.F., G.G., T.R., E.M-C., Y.D., V.P., and P.S-P.; resources, A.S-A., M.C., J.E., J.R-U., U.L., A.A., E.M-C., Y.D., V.P., and P.S-P.; data curation, A.S-A., B.F., U.L., and E.M-C.; writing-original draft preparation, A.S-A., B.F., M.C., and P.S-P.; writing-review and editing, A.S-A., B.F., M.C., J.E., J.R-U., U.L., A.G., P.S., X.B., R.C., M.E., A.A., J.G-P., G.R., A.F., N.R., M.F., N.L., A.S., M.P., A.F., G.G., T.R., E.M-C., Y.D., V.P., and P.S-P.; visualization, A.S-A., B.F., M.C., J.E., J.R-U., U.L., A.G., P.S., X.B., R.C., M.E., A.A., J.G-P., G.R., A.F., N.R., M.F., N.L., A.S., M.P., A.F., G.G., T.R., E.M-C., Y.D., V.P., and P.S-P.; supervision, A.S-A., M.C., J.R-U., and P.S-P.; project administration, A.S-A., M.C., J.E., J.R-U., U.L., E.M-C., Y.D., V.P., and P.S-P.; all authors: A.S-A., B.F., M.C., J.E., J.R-U., U.L., A.G., P.S., X.B., R.C., M.E., A.A., J.G-P., G.R., A.F., N.R., M.F., N.L., A.S., M.P., A.F., G.G., T.R., E.M-C., Y.D., V.P., and P.S-P. have read and agreed to the published version of the manuscript.

Funding: This research received no external funding.

Acknowledgments: Centre Estudis Epidemiològics sobre les Infeccions de Transmissió Sexual i Sida de Catalunya: Anna Bordas, Alexis Sentis, Jordi Aceiton, Jordi Casabona; Agència de Qualitat I Avaluació Sanitàries: Lluís Martínez-López; Hospital Comarcal de 1'Alt Penedès: Lluís Delgado; Consorci Sanitari Alt Penedès-Garraf: Ernesto Mónaco; Hospital de Barcelona: Carlos Herrero; Hospital CIMA de Barcelona: Isabel Casas Hospital Universitari General de Catalunya: Pere Sala, Vanessa Laveglia; Hospital Universitari Dexeus: Grisel Vilagrasa, Cristina Bonjoch; Hospital Universitari Germans Trias i Pujol: María Méndez; Hospital Universitari Josep Trueta i Hospital de Santa Caterina de Girona: Francesc Ripoll, Borja Guarch; Hospital General de Granollers: Pilar Llobet, Berta Pujol; Hospital de Igualada i Atenció Primària de l'Anoia: Isabel Zambudio; Hospital Universitari Arnau de Vilanova, Lleida: Laura Minguell, Nuria Visa Reñe, Fernando Paredes Carmona; Hospital Althaia Manresa: Zulema Lobato; Consorci Sanitari del Maresme, Hospital de Mataró: Anna Vidal, Rosario Diez; Fundació Hospital Sant Joan de Déu de Martorell: Ana Moreira, Evelyn Berbel Palau; Hospital de Nens de Barcelona: Álvaro Díaz-Conradi; Hospital d’Olot i Equip Pediàtric Territorial Garrotxa i Ripollès (EPTGiR): Ferran Campillo, Stephan Schneider; Hospital de Palamós, Serveis de Salut Integrats del Baix Empordà: Joan Manuel Torres; Hospital Sagrat Cor i Hospital Quirón Salud del Vallès: María 
Milà; Hospital Clinic Maresme-Grup Creu Groga: Víctor Sanmartín; Consorci Sanitari de Terrassa: Abel Martínez, Iris González; Hospital Mútua de Terrassa: Emiliano Mora, Tomàs Pérez-Porcuna, Roger Garcia-Puig; Consorci Corporació Sanitària Parc Taulí de Sabadell: Romina Conti; Hospital Universitari de la Santa Creu i Sant Pau: José María Valle T-Figueras; CM Teknon: Olga Martínez; Hospital Universitari Joan XXIII de Tarragona: Blanca Rosich, Arantxa Gómez; Hospital Vall D’Aran: Imma Caubet; Pius Hospital de Valls: Clara Calbet; Hospital General de Vic: Montse Ruiz García; Hospital Universitari Vall d'Hebron de Barcelona: Raisa Morales, Pepe Santos; EAP Ripollet: Ana M Moreno, Imma Bayona; Hospital de Mollet: Pilar Gussinyé; CAP Poblenou: Carlos Losana; Gran Sol Barcelona: Teresa Fenollosa; Equip Territorial de Pediatria del Garraf: Coral Moreno, Joan Azemar; SAP Osona: Silvia Burgaya; Atenció Primària Girona: Xavi Durán; Hospital de Figueres (Alt Empordà): Pili Villalobos; EAP El Carmel: Mònica Vila; ABS Eixample, Lleida: Daniel Gros Esteban, Silvia Prado Muñoz; ABS Balàfia-Pardinyes, Lleida: Gemma Terrer Manrique; ABS Pla d'Urgell (Mollerussa), Lleida: Neus Piqué Palacín, Mireia Carulla Bonjoch; CAP Montblanc: Àngels Naranjo; CAP Llibertat Reus: Olga Salvado; CAP Cambrils: Lorena Braviz; CAP Almacelles: Maria Chiné Segura; ABS Les Borges Blanques: Mireia Biosca Pàmies; ABS Cappont Lleida: Evaristo Galdeano Borra; CAP Onze de Setembre. Lleida: Mercé Escuer Morell; ABS Rural Sud-Granadella: Raquel Plasencia Atienza; ABS Bordeta-Magraners (Lleida): Mercé Giribet Folch; CAP Sort/Hospital Pallars: Rebecca Oglesby; Hospital Quirón-Salud Barcelona: Isa Vives; Equip Territorial de Pediatria de l'Alt Penedès: Silvia Sabate Alborna, Vanesa Fernandez Diaz, Cintia Ago; CAP Can Serra Hospitalet de Llobregat: Anna Mํㅗ Ristol; CAP el Clot: Laura Dominguez; ABS Bellpuig, Lleida: Anna Castan Campanera; Corporació del Maresme i la Selva: Javier Cantero; Equip Territorial de Pediatria del Garraf: Cinta Valldepérez; Hospital Universitari San Joan de Reus: Marc García Lorenzo; EAP Salt: Laia Solé; CAP El Serral (Sant Vicenç dels Horts): Josep de la Flor.

We also want to thank the study collaborators: research technicians Ms. Ingrid Carbones, Ms. Eva del Amo; and research nurses Ms. Saida Ridao, Ms. Montserrat García, Ms Jenifer Davila and Ms. Cristina Montiel for their collaboration in blood extraction, samples processing and telephone interviews, and all the patients and their families for their participation in this study.

This study was carried out using anonymized data provided by the Catalan Agency for Quality and Health Assessment (AQuAS), within the framework of the PADRIS Program.

Conflicts of Interest: The authors declare no conflict of interest.

\section{References}

1. Park YJ, Choe YJ, Park O, et al. Contact tracing during coronavirus disease outbreak, South Korea, 2020. Emerg Infect Dis. 2020 Oct [date cited]. https://doi.org/10.3201/eid2610.201315

2. Lei $\mathrm{H}, \mathrm{Xu} \mathrm{X}, \mathrm{Xiao} \mathrm{S}, \mathrm{Wu} \mathrm{X}$, Shu Y. Household transmission of COVID-19-a systematic review and meta-analysis. J Infect. 2020 Aug 25:S0163-4453(20)30571-5. doi: 10.1016/j.jinf.2020.08.033.

3. Kim J, Choe YJ, Lee J, et al. Role of children in household transmission of COVID-19. Arch Dis Child 2020 Aug 7; archdischild-2020-319910. doi: 10.1136/archdischild-2020-319910.

4. Danis K, Epaulard O, Bénet T, et al. Cluster of coronavirus disease 2019 (Covid-19) in the French Alps, 2020. Clin Infect Dis 2020. doi:10.1093/cid/ciaa424.

5. https://www.rivm.nl/en/novel-coronavirus-covid-19/children-and-covid-19.

6. Heald-Sargent T, Muller WJ, Zheng X, Rippe J, Patel AB, Kociolek LK. Age-Related Differences in Nasopharyngeal Severe Acute Respiratory Syndrome Coronavirus 2 (SARS-CoV-2) Levels in Patients With Mild to Moderate Coronavirus Disease 2019 (COVID-19). JAMA Pediatr.2020;174(9):902-903. doi:10.1001/jamapediatrics.2020.3651.

7. Han MS, Choi EH, Chang SH, et al. Clinical characteristics and viral RNA detection in children with coronavirus disease 2019 in the Republic of Korea. JAMA Pediatr. Published online August 21, 2020. doi:10.1001/jamapediatrics.2020.3988.

8. https://dixit.gencat.cat/web/.content/home/02actualitat/01_noticies/2020/resolucioSLT7202020.pdf

9. Teherani MF, Kao CM, Camacho-Gonzalez A, et al. Burden of illness in households with SARS-CoV-2 infected children [published online ahead of print, 2020 Aug 11]. J Pediatric Infect Dis Soc. 2020; piaa097. doi:10.1093/jpids/piaa097

10. Ludvigsson JF. Children are unlikely to be the main drivers of the COVID-19 pandemic - A systematic review. Acta Paediatr 2020 Aug; 109(8):1525-1530. doi: 10.1111/apa.15371. 
11. Davies NG, Klepac P, Liu Y, Prem K, Jit M; CMMID COVID-19 working group, Eggo RM. Age-dependent effects in the transmission and control of COVID-19 epidemics. Nat Med 2020 Aug; 26(8):1205-1211. doi: 10.1038/s41591-020-0962-9. Epub 2020 Jun 16.

12. Posfay-Barbe KM, Wagner N, Gauthey M, et al. COVID-19 in Children and the Dynamics of Infection in Families. Pediatrics. 2020; 146(2): e20201576.

13. Ehrhardt J, Ekinci A, Krehl H, et al. Transmission of SARS-CoV-2 in children aged 0 to 19 years in childcare facilities and schools after their reopening in May 2020, Baden-Württemberg,Germany.EuroSurveill.2020;25(36):pii=2001587. https://doi.org/10.2807/1560-7917.ES.2020.25.36.2001587.

14. Link-Gelles R, DellaGrotta AL, Molina C, et al. Limited Secondary Transmission of SARS-CoV-2 in Child Care Programs - Rhode Island, June 1-July 31, 2020. MMWR 2020 Aug 28; 69(34):1170-1172. doi: 10.15585/mmwr.mm6934e2.

15. Viner RM, Russell SJ, Croker H, et al. School closure and management practices during coronavirus outbreaks including COVID-19: a rapid systematic review. Lancet Child Adolesc Health 2020;4:397-404. 